\title{
Treaty-text Loyalists' Burden with Subsequent State Practice
}

\section{Benedict Abrahamson Chigara ${ }^{1}$}

Accepted: 1 March 2021 / Published online: 6 April 2021

(C) The Author(s) 2021

\begin{abstract}
The role of subsequent state practice in the procedural law of treaties, and in the determination of consent in the implementation of treaties have become the subject of much scholarly debate in recent times. The UN International Law Commission has devoted copious amounts of study time into these issues under the distinguished guidance of Georg Nolte as Special Rapporteur. Ph.D. theses and research monographs, journal articles and commentaries have appeared on the matter, but the debate persists. At one end of this debate are treaty-text loyalists that reject the potential of subsequent state practice to modify what they regard as 'solemn oaths' taken by states when they conclude and adopt a treaty. That 'temporal declaration of consent' by states to be bound by a treaty regime is for them sacrosanct. At the other end are analytical jurisprudence scholars who appear to insist upon a purpose test approach to the matter. This article evaluates treaty-text loyalists' arguments under current state practice on treaty implementation across a number of disciplines. It shows that the view that 'temporal consent' supremely prohibits the modification of treaties through subsequent state practice is exaggerated. Moreover, the 'solemn oaths' perception of treaties is not supported by recent examples of treaty implementation.
\end{abstract}

Keywords Subsequent practice $\cdot$ Treaty interpretation $\cdot$ Consent $\cdot$ Treaty modification $\cdot$ Compromis $\cdot$ Purpose test $\cdot$ Treaty-text loyalists

\section{Introduction}

Article 38(1) of the Statute of the International Court of Justice (ICJ) is a very deliberate, technical attempt to establish order in the practice of international law. It constrains tribunals from applying norms other than those deriving from the listed sources, unless of course the parties themselves by agreement empower the Court

Benedict Abrahamson Chigara

ben.chigara@qu.edu.qa

1 College of Law, Qatar University, Doha, Qatar 
to decide their case ex aequo et bono (Art. 38(2)) — consent generally remaining an indispensable attribute to law-making and practice in international law-North Sea Continental Shelf cases (1969). ${ }^{1}$

The purpose of the sources of law listed in the Statute of the ICJ is not to mutually distinguish them from one another per se as is sometimes assumed. Rather, it is to establish a band of sources that work in concert to prevent or minimize a possible circumstance of non-liquet ${ }^{2}$ as appeared to occur in the Corfu Channel case (1949). ${ }^{3}$ In that case the ICJ embarrassingly ended up imposing a norm of custom, contrary to Article 38(1)(b)'s own secondary rules of recognition. Perhaps resorting to general principles of law recognized by civilized nations (Art. 38(1)(c)) might have been the better option as there was neither treaty law nor customary law that was specific to that sensitive dispute between the United Kingdom and Albania.

The sources listed in sub-paragraphs (a)-(d) of Article 38(1) also support one another's manifestations and, further, the band's common purpose of guiding the hand of the practitioner in the practice of international law. Therefore, contrary to treaty-text loyalists' claims that appear to be obsessed with an 'unfounded solemnization of the treaty regimes approach' by focusing only on a specific time-bound submission of consent as the moment when states' involvement in law-making is concluded, and thereafter, the treaty regime assumes a separate existence of its own, this article proposes an 'elastic approach to consent' in treaty law as a better way: (i) to explain current state practice regarding subsequent practice in treaty implementation; (ii) to better understand the function of general principles of law recognised by civilised nations in treaty interpretation; and (iii) to also understand the possible uses of custom in treaty interpretation.

This approach has the benefit of maintaining the unity of the band of sources of international law that is consistent with their function to both: (i) constrain the hand of the Court, and (ii) establish a functional and efficient concert of sources of international law. It supports the view that subsequent state practice could and should be understood as a corollary of consent in treaty law-making and not a threat to it. This opinion recognizes the role of subsequent state practice in the procedural law of treaties as encapsulating both the interpretation and the modification of the content of a treaty to allow for a more flexible implementation that is not constrained by idealistic formalisms that are obsessed with laws as commands at the expense of achieving the goals of the relevant community under a treaty regime.

This view is consistent with Myres McDougal's conceptualization of an international agreement 'as a continuing process of communication and collaboration between the parties in the shaping and sharing of demanded values' ${ }^{4}$ It is consistent with Richard Gardiner's view that Articles 31 to 33 of the Vienna Convention on the Law of Treaties (VCLT) (1969) ${ }^{5}$ on treaty interpretation should be viewed more

\footnotetext{
1 ICJ Reports 1969, p. 3.

2 See ILC (2019b), para. 95.

3 ICJ Reports 1949, p. 41. See also Chigara (2001), p. 167.

4 Gardiner (2018), p. 335. See also Fox (2010) pp. 59-74.

51155 UNTS 331.
} 
properly as a combination of inexhaustive general principles, and as a starting point, and also as a framework because 'the general understanding is that treaty interpretation is not simply about the application of Articles 31 to 33 of the VCLT'. 6

Moreover, the clamour over the years for a 'scientific approach' to treaty interpretation simply required that 'all available evidence should be brought to bear in the task of treaty interpretation'. ${ }^{7}$ This article argues that subsequent state practice is an indispensable fundamental aspect in the "sundry sources of evidence" ${ }^{8}$ to be relied upon in treaty interpretation and modification.

Recognizing the role of subsequent state practice in the procedural law of treaties in this way is also consistent with John Austin's ${ }^{9}$ analytical jurisprudence which emphasizes the need to analyse key concepts of legal frameworks, including modification, interpretation and subsequent state practice with regard to the procedural aspects of treaty law. According to the Stanford Encylopedia of Philosophy, in spite of challenges from a section of formalist philosophy in recent years, analytical jurisprudence remains the dominant approach to discussing the nature of law. ${ }^{10}$

\section{Consent and the Interdependence of Sources of International Law}

Before his sad passing in September 2017, Cherif Bassiouni had become the champion for the recognition of the future prominence of Article 38(1)(c) of the Statute of the ICJ on general principles of law recognised by civilized nations. He wrote that, going forward, general principles of law recognized by civilised nations would likely become the seminal source of international law because:

As the world's interdependence increases, there will doubtless be greater reliance on international law as a means to resolve a variety of issues which neither conventional nor customary international law is ready to meet. The fast pace of human rights will also bring to the forefront of international, regional, and national adjudication issues which heretofore may have only been viewed as theoretical. The four most pressing issues that will advance to the forefront are: human rights, the environment, economic development, and international and transnational criminality. Even the casual observer will note that in these four areas, conventional and customary international law have not developed the framework, norms, or rules necessary to regulate these issues, nor is it likely that these two sources of law will catch up with the needs of the time. Thus, it is quite likely that 'General Principles' will become the most important and influential source of international law [...]. Existing needs and conflicts will necessarily require some legal basis for their satisfaction and resolution. In this case, the definition, identification, and functional use of 'General

\footnotetext{
${ }^{6}$ Gardiner (2018), p. 336.

7 Ibid.

8 Ibid.

9 Stanford Encyclopedia of Philosophy (2001).

10 Ibid.
} 
Principles' will require more rigorous attention than has thus far been given to these questions. For the same reasons, greater rigour will be demanded of the rather loose manner in which jus cogens has been defined, identified, and applied by various writers. ${ }^{11}$

General principles of law derive from treaties, custom, national constitutions, judicial decisions, regional and organizational proclamations, etc. They show the unity and not the mutual exclusivity of a legal system's recognized sources of law. They are the confluence of all the perceivable sources of international law, from soft law to treaty norms.

Bassiouni's inclinations were confirmed by the incorporation of general principles of law into the programme of work of the International Law Commission (ILC) and by the appointment of Commissioner Marcelo Vázquez-Bermúdez as Special Rapporteur for the study of general principles of law recognized by civilized nations at its seventieth session in 2018 - making it a standing feature on the ILC agenda. ${ }^{12}$

Literature $^{13}$ routinely describes general principles of law recognised by civilized nations as "cardinal principles of the legal system, in light of which international law is to be interpreted and applied' ${ }^{14}$; and also as 'obvious maxims of jurisprudence of a general and fundamental character'. ${ }^{15}$ They have also been characterised as the equivalent of an international common law that sprouts out of the core concepts, norms and rules of national legal systems. They are 'foundational ordering norms in a global, interdependent community'. ${ }^{16}$

In law-making, the consent of states is an example of such norms. The Lotus case placed consent at the core of the law of obligations in international relations by stating that the rules of law binding upon states are only those that emanate from their own free will. ${ }^{17}$ An accurate characterisation and representation of consent has become critical to resolving the ongoing debate on whether the subsequent practice of states could justifiably modify treaties by giving it priority in treaty interpretation under Article 31(3) of the VCLT. ${ }^{18}$

Mathew Craven writes that: 'mutual consent of the parties, and the reality of consent on the part of each party, is an essential condition of the validity of any treaty'. ${ }^{19} \mathrm{He}$ insists that the idea of consent operates to produce 'that which it seeks to give effect: namely, a legal world configured around the idea that it is the systematic outcome of acts of collective free will rather than of coercion'. ${ }^{20}$

\footnotetext{
11 Bassiouni (1989-1990), p. 769.

12 ILC (2019a).

13 See also Jain (2016), p. 114; Schlesinger (1957), pp. 734-753; Ford (1994), pp. 35-86; ILC (2019b), para. 95.

14 Bassiouni (1990), p. 770 (emphasis added).

15 Ibid., p. 770.

16 Ibid., p. 773.

17 PCIJ Series A No. 10 (1927), p. 18 (emphasis added).

18 See Buga (2018a); Nolte (2013); Fox (2010), pp. 59-74; Bowman and Kritsiotis (2018); Tladi (2018).

19 Craven (2018), p. 103.

20 Ibid., p. 104.
} 
Subsequent state practice can clarify what states believed they had achieved and consented to when they entered into a treaty regime. Nonetheless, treaty-text loyalists insist that states should remain bound by what they had previously signed up to, unless of course they follow the treaty's own recognised procedures for rectifying its strictures. By this insistence, treaty-text loyalists risk undermining the very purpose of entering into treaty regimes because law is a method for pursuing specific community goals. It is not to be mistaken for an exercise in idealising formalisms to be infatuated with.

Treaty-text loyalists insist that consent is temporal. Consequently, states are bound by what they have consented to at a particular time in the past. ${ }^{21}$ An alternative view is that the fast-moving pace of international life requires a more fluid determination of what states have consented to, in order to keep the law up to speed with the needs of those it regulates.

Particularly in lex specialis regimes, the probative value and influence of wider principles of international law such as consent is elevated because of the specific and special purpose that those regimes serve. Examples include the law of the World Trade Organization (WTO), the law of the World Intellectual Property Organization (WIPO), the law of the sea (LOS), the law of the International Criminal Court (ICC), and international environmental law. The general and wider source of international law-principles of international law recognised by civilized nations that Bassiouni foresaw as potentially becoming more critical to the future efficacy of the international legal system, are particularly helpful in assessing illegality in the international legal system by, for instance, showing the inconsistency of new developments with, for example, the requirement of the rule of law.

In the Kadi cases, ${ }^{22}$ the emerging over-enthusiastic practice of the CounterTerrorism Committee of the UN Security Council of listing persons suspected of involvement in terrorist offences, and issuing international sanctions against such persons and entities without any attempt whatsoever at alerting them to these suspicions, or giving them an opportunity to rebut them, was struck down by the Court of Justice of the European Union (CJEU) for its inconsistency with the general requirement of the principle of the rule of law, and more specifically, the requirements of natural justice.

In the Asylum case, ${ }^{23}$ the ICJ stated that any state claiming that lex specialis had become binding on another member must show that the other member state had actually consented to that rule. Therefore, the requirement of consent remains a general principle of law recognised by civilized nations.

In the area of treaty law, the question of whether subsequent state practice could modify treaty obligations by recognizing it as law, something that is totally contrary to the express terms of a treaty adopted at some point in the past without ever going through the tedious, burdensome and 'outcome uncertain' process of formal treaty

\footnotetext{
21 Crawford (2013) p. 30.

22 Case C-402/05 P and C-415/05 P, Kadi and Al Barakaat International Foundation v. Council and Commission [2008] ECR I-6351. See also Kokott and Sobotta (2012), pp. 1015-1024.

23 ICJ Reports 1950, p. 266.
} 
amendment-Articles 39-41 VCLT, has given rise to the question of whether consent should be viewed as something that is static or fluid/elastic to encapsulate subsequent state practice that may have the effect of modifying a treaty regime.

\section{Fluidity/Elasticity of Consent}

Under this approach, consent is not, as treaty-text loyalists seem to suggest, something that is firmly and immovably stuck to the masts of the treaty adoption process. Rather, it can elasticly and flexibly inform and absorb subsequent state practice on a treaty regime, pointing to the true intent of the parties, and thereby solidifying the treaty by agreed practice regarding its provisions. An immutable benefit of this approach is that it would encourage universal state participation in treaty regimes and minimise the possibility of denunciation or even the revocation of treaties by member states parties that for some reason experience aggravation with the rigid implementation of a treaty regime.

The fluid/elastic consent approach recommends the view that upon the adoption stage, states concur on the establishment of a regime whose framework they have determined. However, it is the energy of state practice subsequent to the adoption of a treaty that confirms and solidifies the intent of the parties to the treaty. This is clear from the ordinary meaning of the text of Article 31(3) of the VCLT which provides that subsequent state practice is the objective matrix that establishes the agreement of the parties regarding the interpretation of the treaty.

The fluid/elastic consent proposition recommends that subsequent state practice functions to both confirm and clarify what states actually believed they were consenting to in the milieu of treaty conclusion. The belief of what obligates statesopinio juris sive necessitatis-is an evidentiary requirement of customary international law. Therefore, its presence in the confirmatory and clarificatory role of subsequent state practice in treaty interpretation should be regarded as part and parcel of the drumbeat of the concert, and not the individualisation of sources of international law.

However, this suggestion is noise to the ears of treaty-text loyalists who are obsessed with loyalty to the form of the words used in treaty provisions when the treaty was actually adopted. Marcelo Kohen urges reliance on formal texts. ${ }^{24}$ The intrinsic virtues of formal agreements inherent in this call are difficult to find when we apply the purpose test to treaty regimes. Moreover, the exigencies of state practice in modern international relations favour a fluid and more flexible/adaptable law-making process that rigid adherence to compromis-engineered treaty texts may hinder.

Kwakwa writes that rule-making in international law must be characterised by an intrinsic, rapid and effective 'ability to reflect and respond to the changing needs and demands of its constituents'. ${ }^{25}$ While rules concerning intellectual property have

$\begin{array}{ll}{ }^{24} & \text { Kohen (2013), p. } 34 . \\ { }^{25} & \text { Kwakwa (2002), p. } 179 .\end{array}$ 
traditionally been adopted by the treaty method, the rapid advances in technology have resulted in a situation where the

traditional treaty-making processes are now unsuited to the realities of intellectual property law. This poses a challenge to the World Intellectual Property Organization (WIPO) - the specialized agency of the United Nations (UN) whose mandate is to promote and protect intellectual property worldwide. In order to ensure WIPO's continued relevance, viability, and legitimacy in an increasingly globalized world, the Organization must adapt its traditional rulemaking processes by adopting more rapid, transparent, effective, and politically acceptable means of norm creation. ${ }^{26}$

It is not even the purpose of treaties to constrain member states parties to a rigid loyalty to a form of words. Rather the purpose of treaties is generally to facilitate inter-state behaviour for states' own benefit by distinguishing acceptable conduct from unacceptable conduct. A lawyer may be obsessed with a form of words for his/her own satisfaction that the words have been proved right. But such a fascination with formal texts may breed dysfunctionalism in the practice of the law among its constituents. It may also breed a frustration that limits rather than promotes the law's efficacy and reliability among its users.

Should states be wary of, inter alia, lawyering treaty-text loyalists whose preoccupation is to snare them with formal lexical texts for the sake of it, rather than the pursuit of the purpose of treaty objectives? The purpose of intellectual property treaties, according to Kwakwa, is to "provide adequate solutions to changes resulting from new economic, social, cultural, and technological developments ${ }^{27}$ and not to facilitate or service some text adherence game for lawyering's sake.

Sources of law should not end up as only technical lawyering mechanisms. Rather, they should chiefly be practical tools for enhancing states' mutual conduct in pursuit of particular outcomes. Treaties should never become or end up as yokes around states' necks - to be borne whatever the cost as a consequence of obsessive formalism.

\section{Treaty-text Loyalists' Burden: An Obsession with Form Rather than Purpose?}

Treaty-text loyalists strongly oppose any suggestion that adopted treaties may be modified by anything other than by the measures authorised by the treaty itself, and in accordance with all the procedures laid down in the treaty itself. Anything else, they argue, risks destabilising the VCLT's contemplations of the procedural framework of treaty law. In particular, anything else would risk a kind of infidelity to, and a breach of Article 31 of the VCLT on treaty interpretation. One post in the EJIL talk raises what it describes as a:

\footnotetext{
26 Ibid.

27 Ibid., p. 183.
} 
[...] concern about an apparent, almost surreptitious, attempt by the International Law Commission to elevate subsequent agreements and subsequent practice as tools of interpretation to the same level as the more objective tools outlined in article 31(1) of the Vienna Convention of the Law of Treaties. [...] However, there is a real possibility - a possibility which could risk the stability of treaties - that the ordinary meaning of the words of a treaty, in their context and in light of the object and purpose of the treaty could give way to ever-changing moods of states expressed through subsequent agreements and subsequent practice. If states don't like the terms of the treaties they have adopted, they should amend it through the means provided for in the treaty or in the customary rules on amendments of treaties. Amendment through interpretation, a real likelihood if subsequent agreements and subsequent practice were elevated to an independent status of equal value-perhaps some day even greater - to ordinary meaning, in context and in light of the object and purpose, would be a dangerous course. It is hoped that this implicit suggestion in the work of the Commission is not taken up by the practice of courts in the application of article $31 .^{28}$

So, is there concern here that Courts might follow the International Law Commission's lead on this matter? But they already have, such as for example in the Case Concerning Pulp Mills on the River Uruguay (Argentina v. Uruguay). ${ }^{29}$ Courts have been in step with this approach for a while now, including in Commission of the European Communities v. Ireland. ${ }^{30}$ Any sympathy with this firm-mast approach to treaty texts risks misunderstanding treaties as artefacts of statecraft, and not masters over states' interests. Therefore, the state interest evident in the making and implementation of treaties could never end. As Cassese ${ }^{31}$ wrote, states are the backbone of international law. If they disappeared today, international law as we know it would disappear with them, too.

States choose or agree to make treaties and to participate in their regimes, or they choose or agree not to. The process of treaty-making does not guarantee a perfect outcome-particularly in multilateral treaty regimes where almost 200 states are involved, often with some of them totally opposed to, and others ambivalent to, and yet still others championing the proposed treaty regime. Treaty law ought to allow the correction of any imperfections that become apparent in a treaty regime without taking the long road of rectification measures provided for in the treaty itself. A failure to recognize this may compel states to increase their hesitancy to ever sign up to treaty regimes. The instances of stillborn treaties and of 'less than universal treaties' would increase and not decrease. Insisting that a treaty regime must be kept going in the form adopted, when a nudge to subsequent state practice would clarify what

\footnotetext{
28 Tladi (2018) (emphasis added).

29 Judgment of 20 April 2010, ICJ Reports 2010, p. 14, at p. 18.

30 Case C-459/03 [2006] ECR I-4657.

31 Cassese (1986), p. 74.
} 
states believed they were actually agreeing to, is difficult to justify. It would beg only one question-why?

In fact, subsequent state practice may be a smart way to develop a treaty regime. It would be less costly, too. There will always be unforeseen challenges with any new treaty regime. Trying to use the treaty amendment procedures established under the treaty itself may be frustrating where, for instance, an urgent need arises for rectifications in the immediate aftermath of the operationalization of the treaty regime. The amendment procedures contained in the treaty provisions may prove to be short straw, too, for the unforeseen emergent challenge(s). This could, depending on the subject matter of the treaty, boil into frustration with and rejection of the treaty altogether.

If states make treaties and still choose whether to participate in them or not, how and why could they not use subsequent practice to confirm their true intent in light of the often chaotic tactics involved in treaty conclusion and treaty adoption diplomatic conferences? In their chronicle of the adoption of the Rome Statute (1998) establishing the International Criminal Court (2002) (Rome Statute), ${ }^{32}$ Philippe Kirsch and John Holmes write that in the final days of the conference:

The bureau was still faced with an enormous problem. No agreement existed on the fundamental questions as the conference commenced its final days. The CW chairman urged delegations, publicly and privately, to carry out consultations on the remaining problems, with the assistance of coordinators. As the final week drew to a close, solutions were found to a number of sensitive issues, but the key problems in part 2 remained outstanding, despite pressure from the chairman and the bureau, and lobbying by pro-court states and even the Secretary-General of the United Nations. ${ }^{33}$

As the third week of the conference drew to a close and the bureau took stock of the state of negotiations, [...] the draft statute had ground to a near standstill. [...] The road to an acceptable text of part 2 was neither certain nor apparent. States were reluctant to agree to compromises on specific issues without knowing how the entire package would emerge. More fundamentally, some states, as it turned out, simply could not accept much of the compromise language put forward by coordinators, and therefore strenuously defended their positions, preventing unbracketed texts from emerging. ${ }^{34}$

I will come back to the intricate issues around the conclusion and adoption of the ICC regime to elaborate on the burden of the treaty-text loyalists in Sect. 8 below, where I examine treaties as creations of chance-sometimes unique, rare and uncommon opportunities that regime champions will do anything not to miss or waste. This often results in last gasp deals in treaty adoption conferences. All this contradicts the 'solemn and unequivocal' impression of treaty adoption conferences

\footnotetext{
${ }^{32}$ See https://www.icc-cpi.int/resource-library/documents/rs-eng.pdf (accessed 24 February 2021).

33 Kirsch and Holmes (1999), p. 9.

${ }^{34}$ Ibid., p. 5 (emphasis added).
} 
that is implied all the while in treaty-text loyalists' argumentations against admitting subsequent state practice into the scheme for modifying treaty regimes.

It is necessary to state here that subsequent state practice is very much a dynamic of international law, and one that the ILC itself has studied for a while now. At its sixty-fourth session (2012) the ILC changed the format of its work on this topic and its title with effect from 2013 from 'Treaties over time' to 'Subsequent agreements and subsequent practice in relation to interpretation of treaties' ${ }^{35}$ Subsequent practice has immense potential to cure the defects arising from last gasp deals commonly experienced at treaty adoption conferences. These deals are meant to seize the moment and to prevent the capitulation of what is often a narrow window of opportunity to reach a compromise and adopt a treaty regime, sometimes following decades of negotiations.

Management of the treaty law-making process, particularly its final stages of adoption, can sometimes give the impression of travails almost akin to childbirth, except that it will only be the birth of a new treaty regime. Negotiators shuttle endlessly in the corridors of the conference halls, often with very little or no sleep at all for days on end. Tactics, too, on voting times can be utilised to ensure that those parties perceived to be obstructive or hostile cannot derail the process.

Thus, early practice in a treaty regime can sometimes appear to contradict the treaty short of renunciation as happened with the Havana Charter for the International Trade Organization. ${ }^{36}$ Nonetheless, member states parties may insist that they are actually implementing the treaty regime even by their contradictory practices. One benefit of such ripples of inconsistent state practice by member states parties to a newly concluded treaty regime is that it can serve to swiftly clarify, confirm, or correct the intention of the parties and what they believed to have been consenting to when they adopted the treaty. In this sense subsequent state practice may provide a curative platform for the defects injected into the treaty-conclusion process through the chaos of shuttle diplomacy and arm-twisting to reach agreement.

However, treaty modifications linked to subsequent state practice are anathema to treaty-text loyalists who are beholden to the adopted text of the treaty as a definitive, accurate and a sacrosanct record of agreement to be maintained, even worshipedthe still photo finish being more significant to them than the continuing moving picture, even before the colour contours have settled onto the canvas.

But treaty modifications that are linked to subsequent state practice cause no such trauma for pragmatists who see the adopted treaty as a living text ${ }^{37}$ that can be developed or fine-tuned by subsequent state practice. This is particularly because treaties are creations of faire des compromis, and not the total, mutual and equal understanding-intelligere se aequales - that is unconsciously insinuated all the time by treatytext loyalists. For example, in interpreting the Biblical Ten Commandments said to have been hewed on a tablet of stone by God Himself around 1446 BC, St. Paul in

\footnotetext{
35 ILC (2020).

36 See United Nations Conference on Trade and Employment (1947-1948), https://www.wto.org/engli sh/docs_e/legal_e/havana_e.pdf (accessed 24 February 2021).

37 See especially Moeckli and White (2018), p. 136.
} 
53-54 CE (current era) took a moving picture view of the same and clarified the content of a cardinal injunction in his instructions to the church at Corinth thus:

But if any man think that he behaveth himself uncomely toward his virgin, if she pass the flower of her age, and need so require, let him do what he will, he sinneth not: let them marry. Nevertheless, he that standeth stedfast in his heart, having no necessity, but hath power over his own will, and hath so decreed in his heart that he will keep his virgin, doeth well. So, then he that giveth her in marriage doeth well; but he that giveth her not in marriage doeth better. ${ }^{38}$

\section{Treaties as Creatures of faire des compromis}

A useful reminder is that all treaties are productions of faire des compromis. It has been compromise that has led to the successful conclusion and adoption of many a treaty regime for as long as the practice of entering into treaties has existed. No treaty negotiators achieve all they want to in the final text. This makes subsequent state practice the platform for settling any of the splinters left by the messy and often chaotic faire des compromis treaty adoption strategies. If so, then the treaty-text loyalists' burden is one of rejecting the potential curative function of subsequent state practice.

They would rather live with the 'health and safety' issues arising from ores badly protruding out of the 'pig iron' (the treaty) than file them off with the hand file of subsequent state practice. They appear to ignore the fundamental element of all treaties, namely, that they 'are more than just dry parchments or codifications of normative relations fixed in time. A treaty is a continuous process - "at most [...] an approximate replica of a living practice, like a picture of a living person", 39

Irina Buga writes that it must be possible in treaty law to redress shortcomings and ineffective compromises left in the treaty by the drafters. ${ }^{40} \mathrm{~A}$ formal amendment of adopted treaties as a cure for any adoption-process-programmed oversights is probably much harder to achieve than the initial concluding of the treaty itself. Member states parties will now be more aware of the interests to be protected at all costs. ${ }^{41}$ This is clear from the politicisation of the ICC, for instance, into a witchhunt against African situations in its early practice while ignoring similar and sometimes more appropriate cases arising under its jurisdiction elsewhere in the world. ${ }^{42}$ In cases of large multilateral treaty regimes such as the Rome Statute which has 137

\footnotetext{
38 Holy Bible 1 Corinthians Chapter 7 verses 36-38.

39 Buga (2018b), pp. 363-364.

40 Ibid., p. 364.

41 Ibid.

42 Chigara (2019), pp. 412-444.
} 
signatories and 123 states parties, ${ }^{43}$ the formal requirements for amending the treaty can be cumbersome and sometimes unfeasible. ${ }^{44}$

Moreover, additional to the drafting, negotiation, and adoption processes, treaty amendment or revision often requires a similarly time-consuming process of consultations and negotiations.

Such amendments or revisions also are subject to the same requirements of accessions or ratifications before entry into force. The lack of uniformity in the speed with which different states initiate and complete their domestic procedures for adherence to such amendments may result in a complicated and asymmetrical situation among states that are parties to the same agreement, but not to subsequent amendments or revisions. This poses serious problems for the international intellectual property regime, a regime that requires frequent amendments in order to update the treaties concerned. ${ }^{45}$

\section{Ideological Contests Around the Contested Functions of Subsequent State Practice in the Procedural Law of Treaties}

Ideological contests on the integrity of accommodating subsequent state practice within Article 31(1) of the VCLT's procedural framework on the interpretation and modification of treaties are intense. The ILC is collectively seized on the matter with some of its members also fielding separate views in the wider discourse. Georg Nolte $^{46}$ and Irina Buga ${ }^{47}$ have conducted and led useful studies on the topic. The latest contribution on the matter is Michael Bowman and Dino Kritsiotis' Conceptual and Contextual Perspectives on the Modern Law of Treaties. ${ }^{48}$ The matter, though, remains unsettled still.

Notwithstanding, Article 31(3) of the VCLT appears to be clear that it is subsequent state practice that establishes the agreement of the parties. The practice must be relevant, i.e. referring to conduct by the parties in the implementation of the treaty. ${ }^{49}$ It is subsequent state practice that consummates the intention of member states parties. Take a constitutive treaty like the UN Charter, for example, if none of the organs had actually been set up by creating offices and office bearers and rules for filling related vacancies, then it would be correct to say that without the basic relevant subsequent state practice, the formal agreement to establish the UN would not have been established.

But it is not this aspect of subsequent state practice that is at issue when the matter is raised. Rather the salient issue is whether subsequent state practice can lead to

\footnotetext{
${ }^{43}$ UN Treaty Collection (2020), available at https://treaties.un.org/Pages/ViewDetails.aspx? src=TREAT Y\&mtdsg_no=XVIII-10\&chapter=18\&clang=_en (accessed 24 February 2021).

44 See Arts. 121-122 of the Rome Statute.

45 Kwakwa (2002), p. 183.

46 Nolte (2013).

47 Buga (2018a).

48 Bowman and Kritsiotis (2018).

49 Kohen (2013), pp. 34-45.
} 
the modification of a treaty. ${ }^{50}$ What is modification? The difference may be figurative rather than real, thereby obviating the difference. Interpretation implies incompleteness. Therefore, the interpreter has to fathom, create and complete the meaning of that which has not been made apparent or that which is partly incomplete.

Modification implies a departure from the apparent and complete, to something new, perhaps even something not previously intended by the parties, even the opposite of what was previously intended. While both enterprises are creative, their main providers are substantively different. Interpretation is the principal function of the Court/Tribunal while modification is the function of settled state practice that compels the Court/Tribunal to accept a renovation of treaty text formulations. States, too, have an inherent right to interpret treaties. 'Moreover, the power of the General Assembly to request an Advisory Opinion from the Court in no way impairs the inherent right of states parties to the Convention in the matter of its interpretation. ${ }^{51}$

If this is correct, then the distinction between the issues arising from questions about the function of subsequent state practice in the procedural law of treaties, firstly, as an interpretive tool, and secondly, as modifying apparently unambiguous treaty texts, requires further examination as both activities are creative, with neither of them guaranteeing anything except only the speculative adherence to the intention of the parties offered by interpretation. But treaty-text loyalists are adamant that subsequent state practice should not be extended to treaty modification which, if the analogy above is correct, then it already does anyway through interpretation. They attempt this through a wit-splitting process of reductionism and the separation of a treaty from its masters. The masters are now said to be subservient to what they created for the service of their own interests among themselves as principals, more like a robot controlling you and your home instead of the opposite. Writes Kohen,

Treaties are not states' actions that can simply be subsumed under the notion of 'conduct'. They are the most solemn manifestation of the establishment of the coordination of the will of their respective parties. Treaty parties deliberately decided not to keep their agreement informal. What in most cases required lengthy negotiations, the signing of the instrument, parliamentary discussion and approval at the domestic level, ratification by the executive organ, exchange of instruments of ratification or deposit of them, cannot simply be replaced by an interpretation given to some activity on the ground. ${ }^{52}$

If they are not states' actions, then what are they? Why, then, do they need states' ratifications to come into force? Who orders their creation, negotiates them and adopts them if not states themselves, for themselves? Chronicles of the adoption of the Rome Statute suggest that this solemnity claim borders on idealizing about the dynamics of treaty creation in a way that is forlorn from reality. It counters the fact that treaties are creations of compromis under constraints of time especially at the adoption stage where diplomatic last-minute deals and guillotine procedures are

\footnotetext{
50 Ibid., p. 35.

51 Reservations to the Convention on the Prevention and Punishment of the Crime of Genocide, ICJ Reports 1951, p. 20.

52 Kohen (2013), p. 34.
} 
the order of the moment. Often, these last-minute negotiations test the physical and mental resilience of plenipotentiaries; their awareness of the tactics of the end-game of treaty adoption; and their own abilities to ensure that the treaty regime remains as close to their own position on the matter as possible.

It has been suggested that because the negotiating plenipotentiaries rejected ILC Draft Article 38 that sought to recognize subsequent state practice as a mechanism for confirming member states parties' treaty intentions, its utility cannot therefore be extended beyond treaty interpretation to include any modification to the adopted treaty regime. But give a slight thought for a moment to the dynamic of reservations to treaties. Ultimately, states entering reservations and those rejecting proposed reservations and declaring the non-effect of the entire treaty regime as between the reserving state and themselves results in the variation of treaty obligations among states under a common treaty regime.

If this is then correct, it appears to be a big leap from the realities of the recognized state practice of entering reservations to treaties, to claiming that the modification of treaties by subsequent state conduct is neither a conventional rule because it is not included in the VCLT 1969 and 1986, nor a rule of customary international law. ${ }^{53}$ Unless of course the practice of entering reservations to treaties is so uncommon that it is not worth a mention. If subsequent state practice is to be locked away from the toolkit for the possible modification of treaties, a stronger basis than that it is not part of customary international law should be advanced. The practice of entering reservations to treaties is well established. In Reservations to the Convention on the Prevention and Punishment of the Crime of Genocide, ${ }^{54}$ the General Assembly of the UN raised the following questions for the Court's determination:

1. Whether a state ratifying or acceding to the Convention subject to a reservation made either on ratification or on accession, or on signature followed by ratification can be regarded as being a party to the Convention while still maintaining its reservation if the reservation is objected to by one or more of the parties to the Convention but not by others?

2. If the answer to Question 1 above is in the affirmative, what the effect would be of the reservation as between the reserving state and: (a) The parties which object to the reservation? and (b) Those which accept it?

3. What the legal effect would be to the answer to Question 1 if an objection to a reservation is made: (a) By a signatory which has not yet ratified? (b) By a state entitled to sign or accede but which has not yet done so?

The ICJ's responses to these questions severely undermine treaty-text loyalists' arguments that: (i) subsequent state practice should have no effect in treaty modification qua the rule of customary international law, and (ii) the solemn nature of treaties takes away the possibility that states could retain an interest in the character of the treaty regime save as subjects, and should they wish to amend it, then only the measures for doing so enumerated in the treaty provisions are their only recourse.

53 Ibid., p. 37.

${ }^{54}$ ICJ Reports 1951, p. 15. 


\subsection{Should Subsequent State Practice Have No Effect in Treaty Modification qua the Rule of Customary International Law?}

The state practice of entering reservations or declarations to treaties that they have concluded or acceded to is part of treaty nomenclature. It is in a sense a possible 'next phase' in the development of recently concluded treaty regimes. It is customary practice that is recognized and accepted by all states as a dynamic of treaty lawmaking and implementation. For instance, on the occasion of acceding to the United Nations Convention on the Law of the Sea (UNCLOS), ${ }^{55}$ on 21 June 1996 Ireland entered a declaration that modified the application of the dispute settlement provisions of the Convention vis-à-vis its co-members of the European Community (EU) in the following terms:

Ireland recalls that, as a state member of the European Community, it has transferred competence to the Community in regard to certain matters which are governed by the Convention [UNCLOS]. A detailed declaration on the nature and extent of the competence transferred to the European Community will be made in due course in accordance with the provisions of Annex IX to the Convention.

When a dispute arose over alleged UK contamination of the Irish Sea with nuclear waste from its Mox Plant facility in Sellafield, the UK protested against Ireland's referral of their dispute to the International Tribunal of the Law of the Sea (ITLOS) established under UNCLOS for the supervision and resolution of disputes under the Convention. The UK countered that the correct forum for that dispute was not ITLOS, but the CJEU which has jurisdiction over the interpretation of EU law. This is because the EU had itself taken up membership of the UNCLOS, and all EU member states parties had also taken up membership of UNCLOS. Therefore, UNCLOS was very much a part of the EU normative nomenclature.

These circumstances, according to the decision of the CJEU on the matter, firstly had the effect of modifying dispute settlement provisions of UNCLOS. Secondly, jurisdiction over Ireland's dispute with the UK regarding claims of UK contamination of the Irish Sea lay with the CJEU. This would seem odd under the light of treaty-text solemnists and 'treaty separatists from state conduct' because UNCLOS conferred on ITLOS all jurisdiction over disputes arising under the Convention.

However, as the Mox plant case shows, subsequent state practice changed all of that without any notice of the modification requirements under the UNCLOS. And yet this was by all means a massive modification of UNCLOS. Therefore, to maintain their arguments, treaty-text solemnists and 'treaty separatists from state conduct' need to come up with stronger arguments than they have advanced to date.

The outcome of reservation proposals by a member state party to a treaty regime is always to modify for the reserving state, in particular, the applicability of the

\footnotetext{
55 United Nations Convention on the Law of the Sea-UNCLOS (1982), adopted 10 December 1982, entered into force 16 November 1994; 168 States Parties (November 2017), http://www.un.org/depts/los/ convention_agreements/texts/unclos/unclos_e.pdf (accessed 24 February 2021).
} 
so-called 'solemn treaty text' in light of its other state interests. Declarations and reservations entered by states modify treaty regimes regardless of the claims of treaty-text loyalists that treaties are solemn and separate from state conduct. States have used this approach to modify their obligations under certain UN human rights treaties in what Neumayer describes as qualified ratification, i.e. acceptance only of a modified treaty regime. He writes that:

Reservations, understandings, and declarations allow a country to become a state party to an international treaty in a qualified and contingent manner, exempting itself from certain obligations with which state parties are normally expected to comply. Reservations, understandings, and declarations to international human rights treaties are very common-indeed, they are more common than for any other area of international treaty making. ${ }^{56}$

Neumayer's empirical study showed that 'liberal democracies have more, not fewer, reservations, understandings and declarations than do other countries'. ${ }^{57}$

\subsection{The Alleged Solemn Nature of Treaties v. States' Interest in the Development of Treaty Regimes}

The ICJ stated that because the United Nations General Assembly (UNGA) had initiated the Genocide Convention, drawn up its terms and opened it up for signature and accession by states, and because Articles XI and XVI expressly associated UNGA with the Convention, it had a continuing legitimate permanent interest regarding the conditions for states' participation in the Convention. That interest had 'not disappeared with the entry into force of the Convention'. ${ }^{58}$

Subsequent state practice by EU member states parties on the dispute settlement provisions of UNCLOS radically modified dispute settlement among EU member states parties to the UNCLOS regardless of treaty-text loyalists' claims of the 'solemn nature' and 'separate from state conduct' character of treaties. In the MOX plant case (2006)-Commission of the European Communities v. Ireland, ${ }^{59}$ the Commission of the European Commission averred that by instituting at ITLOS its dispute with the United Kingdom of Great Britain and Northern Ireland under UNCLOS, Ireland had failed to fulfil its obligations under Articles 10 and $292 \mathrm{EC}^{60}$

\footnotetext{
$\overline{56}$ Neumayer (2007), pp. 397-398.

57 Ibid.

58 Reservations to the Convention on the Prevention and Punishment of the Crime of Genocide, ICJ Reports 1951, p. 20.

59 Case C-459/03 [2006] ECR I-4657.

60 Consolidated Treaty on European Union and of the Treaty Establishing the European Community, OJ 2002, C 325/01-184.
} 
and Articles 192 and 193 EA. ${ }^{61}$ Those provisions required all disputes regarding the interpretation of EU law to be referred for adjudication to the CJEU. Therefore, the CJEU held that Ireland had breached its obligations under EU law. But both Ireland and the UK were parties to the lex specialis UNCLOS that had unambiguously established a special tribunal-ITLOS ${ }^{62}$ based at Hamburg, Germany, for the resolution of all disputes arising under that Convention.

Simma's view that the consent of the parties is decisive in the determination of the probative value of subsequent state practice to treaty regimes must be correct. He writes that:

[...] the relevance of subsequent practice for the understanding of a legal text appears so natural, [and] so instinctively obvious. Subsequent agreements and subsequent practice are [...] simply more cogent, more peremptory, than the other means we find concocted in art 31 of the Vienna Convention. While it is possible to manipulate the other methods more or less according to the desired outcome, and while one can make interpretation arrive where one's preconceptions (Vorverstaendnis) of what the treaty ought to prescribe [or] want it to [reach], and then garnish the result with that wonderful formula you find in art 31(1), if there exists - and this is a matter of fact-subsequent practice or a subsequent agreement, there is, lege artis, simply no way to get around it. This is it, because the intention of the parties to the treaty will always prevail. And for the same reason there is really no possibility for a third party to distinguish between acts of interpretation, modification, or amendment of a treaty in the absence of a declaration or some other means of clarification provided by the parties to the treaty themselves. It is the consent of the parties which is decisive. ${ }^{63}$

Treaty-text loyalists' obsession with the sacredness of adopted texts is perplexing. It represents perhaps the lawyer's infatuation with texts regardless of their purpose. But it is the object and purpose of a treaty regime that should be central to treaty interpretation. That treaty object and purpose is not backward-looking. Rather, it is always forward-looking in the John Rawls ${ }^{64}$ sense of 'originary genesis' because states establish laws to regulate future not past conduct. A notable difficulty with converse practice is exemplified by lingering questions surrounding the integrity of International Military Tribunal (IMT) laws retrospectively applied to circumstances of the Second World War.

Treaty regimes are to be interpreted in good faith regarding all future relevant applications. Crawford insists that 'the Vienna Convention takes a strictly temporal view of treaties. A treaty is what was agreed by the parties at a given moment in time'. ${ }^{65}$ Therefore, 'the treaty, the primary treaty, is regarded for the purposes of the

\footnotetext{
61 Treaty on the Functioning of the European Union, OJ 2012, C 326/47.

62 See also Ndiaye (2016), pp. 1-40.

63 Simma (2013), p. 46 (emphasis added).

64 Rawls (1999), pp. 118-130.

65 Crawford (2013), p. 30.
} 
law of treaties as the central instrument and the other things have to be taken into account'. ${ }^{66}$ But why, and what are the other things that should be taken into account by the gift of Article 31(3) of the VCLT?

(i) Travaux préparatoires because they can guide us back to the intention of the parties from all that was discussed.

(ii) Subsequent state practice because it demonstrates the belief of the parties about what is required by the law. Moreover, Article 38(1)(b) of the Statute of the ICJ prominently subjects, under its secondary rules of recognition for the formation of custom, what states believed their actions were cementing in law between themselves. ${ }^{67}$

The centrality of subsequent state practice to the implementation of treaties cannot be over-emphasized. The North Sea Continental Shelf cases show that subsequent state practice is capable of transforming treaty norms into general norms of international law. Therefore, treaty-text loyalists' ambivalence towards it may be unhelpful in the overall understanding of sources of international law. Their reductionist approach inclines towards a mutual exclusive understanding of each of the sources listed under Article 38(1)(b). If pursued, it would likely result in some cases, in a situation of non-liquet, where a mutually supportive approach to sources of international law would incline towards the stymieing of the possibility of non-liquet illustrated by the Corfu Channel case. ${ }^{68}$

\section{Customary International Law and the Interpretation of Treaties ${ }^{69}$}

The Case Concerning Pulp Mills on the River Uruguay (Argentina v. Uruguay) ${ }^{70}$ concerned a dispute over Uruguay's planned construction and commissioning of pulp mills. ${ }^{71}$ The parties differed significantly regarding the interpretation and application of a bilateral treaty of 1975 on the optimal utilization of the Uruguay River. The deciding factor in the case was the procedural and substantive obligations arising for the parties from a bilateral treaty of 1975. The Court observed that the 1975 treaty predated the entry into force of the VCLT. ${ }^{72}$ Therefore, in interpreting the terms of the treaty, the Court would have recourse to the customary rules on treaty interpretation as reflected in Article 31 of the VCLT, namely, 'good faith in accordance with the ordinary meaning to be given to the terms of the treaty in their context and in light of its object and purpose'. ${ }^{73}$ That interpretation would take into account

\footnotetext{
66 Ibid., p. 29.

67 North Sea Continental Shelf cases, ICJ Reports 1969, p. 3.

68 ICJ Reports 1949, p. 41.

69 See also Cannizzaro (2014), p. 18; Sinclair (1984), pp. 271-275; Kirgis Jr. (1989), pp. 549-574.

70 Judgment of 20 April 2010, ICJ Reports 2010, p. 14, at p. 18.

71 Ibid., para. 25.

72 In force on 27 January 1980.

73 Judgment of 20 April 2010, ICJ Reports 2010, p. 14, at p. 36.
} 
also, together with the context, 'any relevant rules of international law applicable in the relations between the parties'. ${ }^{74}$

If the current scholarly debate eventually resolves in favour of upholding subsequent state practice as a general principle of law recognized by civilized nations, and as an integral part of the toolkit for interpreting treaties, then the mutuality of state practice as a core requirement among the sources of international law will be confirmed. State practice is one of two limbs required in the formation of custom under Article 38(1)(b) of the Statute of the ICJ. General state practice informs the formation of general principles of law recognized by civilized nations under Article 38(1) (c) of the Statute of the ICJ. Prospectively, the requirement to review subsequent state practice in the implementation of treaties would relieve treaty-text loyalists of their burden that under Article 38(1)(a) of the Statute of the ICJ, subsequent state practice should not be seen to be capable of confirming that which states purportedly consented to as they concluded a treaty regime.

But if the scholarly debate resolves differently, it would only compound the challenges regarding the efficacy of the procedural law of treaty law that already includes waste as human rights treaties can take up to ten years to come into force (International Covenant on Civil and Political Rights and International Covenant on Economic, Social and Cultural Rights); and up to five years for WIPO treaties; and often some treaties never come into force even after nearly a decade or more of multilateral negotiations. The Havana Charter of 24 March 1948 for the establishment of an International Trade Organization ${ }^{75}$ never came into force. The Washington Treaty on the Protection of Intellectual Property in Respect of Integrated Circuits ${ }^{76}$ was adopted in 1989, after more than five years of negotiations. As of 2020, thirty-one years after its adoption, the treaty has been recognized by three states only: Egypt (26 July 1990), Saint Lucia (18 December 2000) and Bosnia and Herzegovina (8 March 2007). ${ }^{77}$ Although it has been incorporated into the World Trade Organization's TRIPS Agreement, ${ }^{78}$ it seems unlikely that the treaty ever will enter into force.

The point is that the sanctity, separability and mutual exclusivity of treaties from general principles of law recognized by civilized nations that include equity, fairness, proportionality, judicial review, and subsequent state practice as a procedural means of interpreting treaties that is impliedly advocated by treaty-text loyalists, is problematic as these sources belong to the same body of sources of law that seeks to serve a common purpose. Members of the same body mutually serve one another as the hand washes all the other parts of the body and the legs transport the body to the next desired destination, while the mouth feeds to ensure there is the energy for every part of the body as required.

\footnotetext{
74 Ibid.

75 United Nations Conference on Trade and Employment (1947-1948), https://www.wto.org/english/ docs_e/legal_e/havana_e.pdf (accessed 24 February 2021).

76 WIPO Administered Treaties (2020), available at https://www.wipo.int/treaties/en/ShowResults.jsp? lang=en\&treaty_id=29 (accessed 24 February 2021).

77 Ibid.

7833 ILM 81 (1994).
} 
Article 38(1) of the Statute of the ICJ is best understood as setting up a concert of sources, and not isolated mutually exclusive peculiar sources whose norms have nothing to do with one another. ${ }^{79}$ Such understanding would relieve treaty-text loyalists of their technical burden that contradicts the purpose of treaties, which is to provide clear rules for the regulation of inter-state contacts. This burden appears to be nothing more than the lawyer's intent to hold on to needless, confusing and unhelpful formalism by 'solemnizing' the treaty text. This burden unconsciously diminishes the more important object and purpose of the treaty regime as perceived and understood by its member states parties. The problem is that the inherent virtues ascribed to treaty texts by treaty-text loyalists are very illusory because treaties are a consequence of much tactical manoeuvring and compromise. This fact counters the absolute finesse claims implied in text loyalists' argumentations for rejecting subsequent state practice as a valid procedural mechanism recognized by civilized nations to interpret treaty agreements.

In fact, as long as states accept, acquiesce in or concede that subsequent state practice demonstrates their current position regarding a treaty regime or provision, lawyers should stop being obsessed with formal texts. Instead they should accept the moving picture of a treaty regime to keep it relevant to the needs of states in a fastmoving dynamic world. WIPO lawyers have conceded that:

Until recently, the system of norm-making at WIPO had been the traditional treaty method. However, in order to remain a viable and credible institution, tasked with the promotion and protection of intellectual property, WIPO has had to devise new and innovative forms of norm-creation that are effective, rapid, and generally accepted by the member states. The formal rigidities and problems associated with the treaty-making process in the field of intellectual property would seem to dictate the need for a more transparent, informal, and consensual method of norm creation. In the last few years, the Secretariat of WIPO has therefore explored other means for advancing the development of international intellectual property law that could supplement the current treaty procedures. ${ }^{80}$

Interestingly, the hand of subsequent state practice in WIPO-administered treaties shows that member states parties' continued ownership of treaty regimes is the norm, very much contrary to the solemn temporal agreement argumentation of treaty-text loyalists that says that states' interest in treaty making ends with the adoption of the treaty regime. ${ }^{81}$ Kwakwa writes that:

WIPO's complicated governance structure has been simplified without any constitutional amendments. This has included the adoption of resolutions by WIPO's General Assembly and other Bodies to adopt practices that are at variance with the textual formulation of the WIPO-administered treaties. In some cases, treaty bodies have simply passed resolutions to adopt practices that are

\footnotetext{
${ }^{79}$ See also Sands and Commission (2010), pp. 39-58.

${ }^{80}$ Kwakwa (2002), p. 191.

${ }^{81}$ See Kohen (2013).
} 
at variance with the textual formulation of the WIPO-administered treaties. In some cases, treaty bodies have simply passed a resolution to wish themselves out of existence, notwithstanding the relevant treaty language establishing them. For example, in September 2000, two of the Organization's Governing Bodies passed resolutions in which they unanimously decided not to meet in the future, and also requested that the Director General of WIPO not convene them. Another three of the Governing Bodies each resolved to dissolve themselves that same year. ${ }^{82}$

\section{Treaties as Creations of Opportunity v. the Solemn Burden Implied in Treaty-text Loyalists' Argumentations}

The requirement of consent for a state to be bound by a rule of international law is a given. ${ }^{83}$ Those involved in treaty development projects always labour with the concern whether states will put pen to paper to transform their draft treaties into law. As the case of the UN Diplomatic Conference of Plenipotentiaries on the establishment of an International Criminal Court (ICC) which commenced work on 15 June 1998 illustrates, the perfect treaty text imagined by treaty-text loyalists does not exist anywhere.

The Draft Statute of the Preparatory Committee that formed the basis of the Rome Conference on the establishment of the ICC was riddled with some 1,400 square bracketed disagreements that had to be addressed in around one month. ${ }^{84}$ In spite of serious disagreements, even in the third week of negotiations and up to the final day of scheduled work, many saw an opportunity that had to be seized because it could not be guaranteed that such a moment could come again any moment soon.

With two days remaining, the Bureau was faced with two alternatives: to propose a final package for possible adoption by the conference, or to report to the plenary that an agreement was not possible and begin preparations for a second session. The bureau seriously weighed the two options and decided to attempt a package deal. If the proposal failed, the second option could be revived. Contacts with delegations reflected a prevailing view that deferring the conclusion of the statute would be a serious mistake. Most delegations were very concerned that a second session would be just as likely to fail, ending hopes for the establishment of an international criminal court for many years, or that it could lead to an unacceptably weakened court. The few delegations that favored deferral were mostly those that were not enthusiastic about the establishment of a strong court to begin with. ${ }^{85}$

\footnotetext{
82 Kwakwa (2006), p. 145.

83 See North Sea Continental Shelf cases, ICJ Reports 1969, p. 3.

${ }^{84}$ Kirsch and Holmes (1999), p. 3.

85 Ibid., p. 10 (emphasis added).
} 
What this shows is that the development of treaties is a doubt-ridden, chance-taking and opportunity-maximizing exercise all of the time, particularly in the concluding moments such as the one described above. Therefore, to suddenly switch from this reality to ascribing awe, absoluteness and temporal fixation to the intention of the parties to the process as treaty-text loyalists seek to do borders on the dramatic. They take a strictly temporal view of treaties that seeks to discount treaty modification by subsequent state practice by insisting that 'A treaty is what was agreed by the parties at a given moment in time'. ${ }^{86}$ But treaty moments are never crystal clear as we have observed above in relation to the conclusion and adoption of the Rome Statute (1998). In fact they are often filled with confusion, wrangling and frustration while flickers of hope linger the process onwards but with no certainty at all that agreement will be reached even as the scheduled deliberation time fades away.

Treaty-text loyalism is problematic for the reasons discussed in this article. It appears to be at variance also with the realistic approach of the ILC that requests the UNGA to merely note by a resolution when it has concluded its work on draft articles on a given topic. Rather than ask for a diplomatic conference to be convened for the purpose of adopting a treaty on the concluded study and recommended draft articles, the ILC now prefers to wait for state practice to confirm the value of their submissions to inter-state relations. The ILC waits on whether states will begin and continue to adopt in their diplomatic exchanges and in their briefs before tribunals, for instance, the content of their submissions on a particular topic. In this way, the state practice of applying ILC draft articles to their situations as the law becomes the midwife that validates and transforms these draft articles into binding norms of international law.

The dynamic of compromis that underpins treaty development inherently and naturally must allow for the demonstration or the firming up of state consent through subsequent state practice which may mean that customary law confirms the true intention of states concerning a treaty. Attempts by temporal treaty-text loyalists to discount the function of subsequent state practice to confirm what states had actually consented to by the treaty adopting a diplomatic conference is worrying not least because it seeks to exclude transparency. There is a sense in which it seems like an attempt to indulge lawyering that is infatuated with legal postulations that have little to do with the purpose of the law and much to do with lawyers themselves.

The significance of this compromis - that matrix of treaty conclusion, is that it must necessarily recognise and accommodate an elastic approach to consent in order to maintain a balance in the dynamic of developing and implementing treaty regimes. This is apparent in Crawford's comment in his salute to Waldock for his contribution to the establishment of the VCLT regime.

We owe the Vienna Convention above all to Humphrey Waldock. It is one of the rather under acknowledged international achievements of that time that he managed to build the Convention text from a rather diffuse body of work by the earlier Special Rapporteurs [...] [that were] going nowhere in terms of a

${ }^{86}$ Crawford (2013), p. 29. 
text that could be adopted by a diplomatic conference. Waldock had the insight to see the Vienna Convention on the Law of Treaties as strictly focusing on what could be achieved by consent: one might say the treaty, the whole treaty, and nothing but the treaty. Accordingly, things are left out of the Vienna Convention which on a broader view might have been there, for example the question of the supersession of treaties by subsequent practice. ${ }^{87}$

The evident hand and force of compromis on the development of treaty regimes must lay to bed any claims of the solemnity of treaty texts. Yes, the occasion may seem or be described as solemn but the texts themselves remain creations of opportunity granted by states themselves as consent ascribing/withholding masters. Whether opportune circumstances exist for possible success should the treaty negotiating champions make a dash for the finish line in the available time is the only consideration that occupies and concentrates the minds of conference plenipotentiaries in the twilight moments of treaty negotiations. This fact makes clear that the process of treaty development is more often than not a gamble. The ILC appears to have learnt this from its long experience of studying different topics and concluding draft articles for UN General Assembly consideration. Some end up in binding treaties with some amendments while others are never seen again. ${ }^{88}$

The ILC's increasing resort to requesting the UNGA not to call for a conference for a review of its concluded draft articles, but to merely note in a resolution that the Commission had concluded its work and then wait to see how state practice responds to the draft articles is very supportive of the elastic approach to consent. It is the practice of states after the submission of ILC draft articles that shapes the law, not the other way round. In short, nothing in the practice of treaty-making processes strongly recommends that treaty texts are laser-beam clear lines-immutable in every sense as treaty-text loyalism suggests.

Last-gasp compromises to ensure the required support of states can weaken treaty regimes both substantively and structurally. States, too, are well aware of this reality and may seek to rectify perceived necessary-for-adoption compromises, often by immediately entering reservations, understandings and declarations on what they have consented to-thereby limiting or modifying the application of the treaty regime against them. All these factors call into question the chief treaty-text loyalists' claims about the solemnness and absoluteness of treaty texts that in their view should discount the role of the modification of treaty regimes by subsequent state practice.

The ICC regime is presently confronted with a metamorphosis of sorts, well beyond what was envisaged by the diplomatic conference that adopted the Rome Statute in July 1998. The UN Security Council which has the mandate to deal with states referred to it for non-cooperation by the ICC itself has received referrals against Chad and Malawi. ${ }^{89}$ In both cases the respective member states parties had

\footnotetext{
87 Ibid. (emphasis added).

88 See especially Bordin (2014), pp. 535-567.

89 See Prosecutor v. Al Bashir, Pre-trial Chamber I, Decision pursuant to article 87(7) of the Rome Statute on the refusal of the Republic of Chad to comply with the cooperation requests issued by the Court with respect to the arrest and surrender of Omar Hassan Ahmad Al Bashir, Case No. ICC-02/05-01/09140, 13 December 2011, paras. 13 and 14.
} 
failed to arrest and surrender former President $\mathrm{Al}$ Bashir upon the request of the Prosecutor while the fugitive was on their territory.

The UN Security Council has remained ambivalent on the matter. Consequently, when on 6 July 2017 Pre-Trial Chamber II found the Republic of South Africa to have breached its obligations under the Rome Statute for similar reasons to Chad and Malawi, it unilaterally froze its hand from referring South Africa to the UN Security Council. How would treaty-text loyalists explain this scenario than as a modification of the referral provisions of the Rome Statute by subsequent state practice? How would treaty-text loyalists explain the 2003 amendments to all the WIPOadministered treaties aimed at formalising certain practices that, "while at variance with the textual formulation of the WIPO-administered treaties, have been followed in practice' ${ }^{90}$

\section{Conclusions}

Treaty-text loyalists have raised issue with the subsequent state practice of states' potential to modify what they call 'solemn oaths' made when treaties are adopted/ ratified. They insist that the subsequent state practice of states in relation to treaty regimes must only conform to those oaths and could not be used to interpret treaties so as to modify the ordinary meaning of adopted treaties. They advance two main arguments in support of their position.

First, that treaties are 'solemn' and separate from state conduct. Secondly, the relevant VCLT provision on how treaties are to be interpreted-Article 31(3)—states that other factors shall be taken into account, but only after the ordinary meaning of the words in the relevant and applicable treaty provision(s) has been considered. In other words, the treaty text alone should be regarded for the purposes of the law of treaties as the central instrument.

But as this article has shown, regarding the first argument, it cannot be accurate to say that treaties have a separate existence to the interest of their instigatorsCase Concerning Pulp Mills on the River Uruguay (Argentina v. Uruguay); and Mox Plant case; and Reservations to Genocide Convention case. Secondly, correctly characterised, treaties are creations of a compromise. This begs the question of the worth of solemnity claims about treaties insisted upon by treaty-text loyalists. The occasion may appear solemn but the treaty text itself is often ragged from the off, with last-minute compromise punctuations, the insertion of words and articles just to satisfy the required supporters in order to carry the treaty across the finishing line.

Moreover, the energetic pace of modern international life challenges claims of supreme immutable oaths fixed in time. In one moment in August 2015 the German

${ }^{90}$ Kwakwa (2006), p. 144. 
Chancellor turned the UN Refugee Convention $(1951)^{91}$ and its Protocol $(1967)^{92}$ on their heads when she asked neighbouring European states to allow refugee-seeking migrants to pass through into Germany. What about the first safe destination country principle contained in the UN Refugee Convention (1951) and decades of practice based on that principle? What about the Dublin Protocol (2003) that required refugees to claim asylum in the first safe country that they reached? 'Merkel swiftly suspended it, allowing refugees who had made (perilous journeys from their countries of origin) to apply for asylum without fear that they would be deported to one of the countries they had passed through. The move gave way to the entry of roughly a million refugees in the space of a year. ${ }^{93}$

Thirdly, the ILC practice of requesting the UNGA to merely note in a resolution the conclusion of its studies and the submission of its draft articles on a previously assigned topic and to await confirmation of the value of their work by state practice would support the view that elasticating state consent by recognising the role of subsequent state practice in treaty interpretation and modification would enhance international law's relevance to its primary subjects that have the power to stop the development of any new norms by withholding their consent.

Fourthly, this also concurs with the ILC's conclusions ${ }^{94}$ that subsequent agreements and subsequent state practice under Article 31, paragraph 3(a) and (b), of the VCLT are therefore:

(i) Objective evidence of the understanding of the parties as to the meaning of the treaty; and

(ii) Authentic means of interpretation, in the application of the general rule of treaty interpretation reflected in Article 31.

The ILC notes that a 'subsequent practice as an authentic means of interpretation under Article 31, paragraph 3(b), consists of conduct in the application of a treaty, after its conclusion, which establishes the agreement of the parties regarding the interpretation of the treaty'.

Treaties are binding on states qua treaties firstly on account of customary international law's basic norm-pacta sunt servanda. Remove that cornerstone of international law and there is not much else left to validate treaties. Secondly, they are binding on account of the general principle of law recognized by civilized nations, namely, consent-North Sea Continental Shelf cases. That consent is not static as a temporal moment of adoption, as treaty-text loyalists insist. Rather it is elastic and extends to the implementation of the treaty which confirms what states believed they had consented to in the milieu of compromise that characterizes the conclusion of most diplomatic conferences upon the conclusion of often decades of treaty negotiations. Therefore, subsequent state practice should be understood as a corollary of consent in treaty law-making and not a threat to it.

\footnotetext{
91 Convention relating to the Status of Refugees, 189 UNTS 150, entered into force 22 April 1954.

92 Protocol relating to the status of refugees, 606 UNTS 267, [1973] ATS 37.

93 'How Germany took in one million refugees but dodged a populist uprising', at Quartz website: https://qz.com/1076820/german-election-how-angela-merkel-took-in-one-million-refugees-and-avoid ed-a-populist-upset/ (accessed 30 August 2020).

94 See ILC (2018).
} 
Treaty law, customary international law and general principles of law recognized by civilized nations combine in this constitutional law on sources of international law to form a band of sources that serves the purposes of international law that are listed in Article 1(1)-(4) of the UN Charter (1945). Attempts to shatter the concert of this band of sources may result in needless confusion about the function of Article 38(1) of the Statute of the ICJ.

In order to realize the goal of pacific settlement of disputes in international relations, this Article 38(1) band of sources, and that means also as aided by the cooperative alliance of their secondary rules of recognition, ought to be assumed to work in concert in order to ensure against the possibility of a circumstance of nonliquet as appeared to occur in the Corfu Channel case. Discourse that claims the superiority of treaty law over all other sources is myopic to this point and unhelpful in the effort to clarify and enhance the doctrine of sources of law in international law.

Perhaps we should never lose sight of the declaration in Article 31(3)(b) of the VCLT itself that it is 'subsequent practice in the application of the treaty which establishes the agreement of the parties regarding its interpretation'. This elastic approach to consent makes for the required flexibility and robustness of process in the making and implementation of international law.

Moreover, the idea of sources of international law presented in Article 38(1) of the Statute of the ICJ makes complete sense, and best serves its purposes when understood not as a list of mutually exclusive sources, but rather as a band of sources intricately combining to manifest each other's existence, giving optimum value of its norms to the enterprise of international relations by minimising the possibility of circumstances of non-liquet. Only if we accept this premise of Article 38(1) can we then unreservedly support the ILC position that 'subsequent practice as an authentic means of interpretation under Article 31, paragraph 3(b), consists of conduct in the application of a treaty, after its conclusion, which establishes the agreement of the parties regarding the interpretation of the treaty'. This in my view is the correct position on the matter because as an idea steeped in state practice, subsequent state practice denotes custom. It shows the dynamic of custom linking up with treaty law to serve the interest of states involved in a particular regime in a manner that allows them to modify or vary their obligations as necessary without the often cumbersome, time-consuming and outcome-uncertain modification procedures contained in the treaty itself.

However, if we insist on a list of mutually exclusive sources in Article 38(1) of the Statute of the ICJ, we risk ending up in the treaty-text loyalists' quagmire of the unfounded solemnity of treaty texts because treaty making is often mired in huge compromises in order to save or not miss the moment because if agreement is postponed or delayed, it may take another few decades to come so close to it ever again. This quagmire leads to the impasse that stubbornly insists without good reason that subsequent state practice could not modify treaties whatever the circumstances. As this essay has shown this proposition is not supported by state practice on the implementation of WIPO and LOS treaties for example. 
Acknowledgements I am grateful to comments by the Board of Reviewers of the NILR on an earlier draft of this article. I am also grateful to the wind beneath my wings: Shalom Chigara, Ben Chigara Jr. and Constance Chigara. Professor Mohamed Elewa Badar, University of Northumbria, enabled me access to an elusive source in my preparation of this work. This work is attributable to the writer alone.

Funding Open access funding provided by the Qatar National Library.

Open Access This article is licensed under a Creative Commons Attribution 4.0 International License, which permits use, sharing, adaptation, distribution and reproduction in any medium or format, as long as you give appropriate credit to the original author(s) and the source, provide a link to the Creative Commons licence, and indicate if changes were made. The images or other third party material in this article are included in the article's Creative Commons licence, unless indicated otherwise in a credit line to the material. If material is not included in the article's Creative Commons licence and your intended use is not permitted by statutory regulation or exceeds the permitted use, you will need to obtain permission directly from the copyright holder. To view a copy of this licence, visit http://creativecommons.org/licen ses/by/4.0/.

\section{References}

Bassiouni C (1989) A functional approach to general principles of international law. Michigan J Int Law 11:768-818

Bordin FL (2014) Reflections of customary international law: the authority of codification conventions and International Law Commission draft articles in international law. Int Comp Law Quart 63:535-567

Bowman M, Kritsiotis D (eds) (2018) Conceptual and contextual perspectives on the modern law of treaties. CUP, Cambridge

Buga I (2018a) Modification of treaties by subsequent practice. OUP, Oxford

Buga I (2018b) Subsequent practice and treaty modification. In: Bowman M, Kritsiotis D (eds) Conceptual and contextual perspectives on the modern law of treaties. CUP, Cambridge, pp 363-391

Cannizzaro E (2014) The law of treaties through the interplay of its sources. In: Tams CJ et al (eds) Research handbook on the law of treaties. Edward Elgar Publishers, Cheltenham, pp 16-38

Cassese A (1986) International law in a divided world. Clarendon Press, Oxford

Chigara B (2001) Legitimacy deficit in custom: a deconstructionist critique. Ashgate, Aldershot

Chigara B (2019) Towards a nemo judex in parte sua critique of the ICC. Int Crim Law Rev 19:412-444

Craven M (2018) The ends of consent. In: Bowman M, Kritsiotis D (eds) Conceptual and contextual perspectives on the modern law of treaties. CUP, Cambridge, pp 103-135

Crawford J (2013) A consensualist interpretation of Article 31(3) of the Vienna Convention on the Law of Treaties. In: Nolte G (ed) Treaties and subsequent practice. OUP, Oxford, pp 29-33

Ford CA (1994) Judicial discretion in international jurisprudence: Article 38(1)(c) and general principles of law. Duke J Int Comp Law 5:35-86

Fox H (2010) Article 31(3)(A) and (B) of the Vienna Convention and the Kasikili/Sedudu Island case. In: Fitzmaurice $\mathrm{M}$ et al (eds) Treaty interpretation and the Vienna Convention on the Law of Treaties: 30 years on. Brill, Nijhoff, Leiden, pp 59-74

Gardiner R (2018) Characteristics of the Vienna Convention rules on treaty interpretation. In: Bowman M, Kritsiotis D (eds) Conceptual and contextual perspectives on the modern law of treaties. CUP, Cambridge, pp 335-362

ILC (2018) Draft Conclusion on subsequent agreements and subsequent practice in relation to interpretation of treaties. https://legal.un.org/ilc/texts/1_11.shtml. Accessed 30 Aug 2020

ILC (2019a) Summaries of the work of the International Law Commission. https://legal.un.org/ilc/summa ries/1_15.shtml. Accessed 30 August 2020

ILC (2019b) First report of the Special Rapporteur on General Principles of International Law. A/ CN.4/732. https://digitallibrary.un.org/record/3805756? $1 n=e n$. Accessed 30 August 2020

ILC (2020) Analytical guide to the work of the International Law Commission: subsequent agreements and subsequent practice in relation to interpretation of treaties. https://legal.un.org/ilc//guide/1_11. shtml. Accessed 30 August 2020 
Jain N (2016) Judicial law-making and general principles of law in International Criminal Law. Harvard Int Law J 57:111-150

Kirgis FL Jr (1989) Some lingering questions about Article 60 of the Vienna Convention on the Law of Treaties. Cornell Int Law J 22:549-574

Kirsch P, Holmes JT (1999) The Rome Conference on an International Criminal Court: the negotiating process. Am J Int Law 93:2-12

Kohen M (2013) Keeping subsequent agreements and practice in their right limits. In: Nolte G (ed) Treaties and subsequent practice. OUP, Oxford, pp 34-45

Kokott J, Sobotta C (2012) The Kadi case-constitutional core values and international law-finding the balance? Eur J Int Law 23:1015-1024

Kwakwa E (2002) Some comments on rulemaking at the World Intellectual Property Organization. Duke J Int Comp Law 12:179-196

Kwakwa E (2006) Institutional and procedural reform at the World Intellectual Property Organization. Int Org Law Rev 3:143-152

Moeckli D, White N (2018) Treaties as living instruments. In: Bowman M, Kritsiotis D (eds) Conceptual and contextual perspectives on the modern law of treaties. CUP, Cambridge, pp 136-171

Ndiaye T (2016) Challenges and prospects of the new law of the sea. State Practice Int Law J 3:1-40

Neumayer E (2007) Qualified ratification: explaining reservations to international human rights treaties. J Legal Stud 36:397-430

Nolte G (ed) (2013) Treaties and subsequent practice. OUP, Oxford

Rawls J (1999) A theory of justice. OUP, Oxford

Sands P, Commission J (2010) Treaty, custom and time: interpretation/application? In: Fitzmaurice M et al (eds) Treaty interpretation and the Vienna Convention on the Law of Treaties: 30 years on. Brill, Nijhoff, Leiden, pp 39-58

Schlesinger RB (1957) Research on the general principles of law recognized by civilized nations. Am J Int Law 51:734-753

Simma B (2013) Miscellaneous thoughts on subsequent agreements and practice. In: Nolte G (ed) Treaties and subsequent practice. OUP, Oxford, pp 46-51

Sinclair I (1984) The Vienna Convention on the Law of Treaties: the consequences of participation and nonparticipation. ASIL Proc 78:271-275

Tladi D (2018) Is the International Law Commission elevating subsequent agreements and subsequent practice? EJIL Talk. https://www.ejiltalk.org/is-the-international-law-commission-elevating-subse quent-agreements-and-subsequent-practice/. Accessed 30 Aug 2020

Publisher's Note Springer Nature remains neutral with regard to jurisdictional claims in published maps and institutional affiliations.

Benedict Abrahamson Chigara holds an FHEA (UK), FInst.LM (London), MCIArb (London), FReachSoc. (London), FGoA (USA), Ph.D. (Nottingham), LLM with Distinction \& Best Performance Award (Hull), BA Joint Hons. (Keele). He is an Affiliate Member of the Centre for Law \& Development, College of Law, Qatar University. 